\title{
The Influence of Direct Compensation and Indirect Compensation through Work Standard Variables as Intervening Variables on Employee Performance at Warung Ayam Goreng Nelongso Klampis, Surabaya
}

\author{
Reny Meliyana Sari ${ }^{1}$, DR. Ir. Rr. Hermien Tridayanti ${ }^{2}$ \\ Narotama University of Surabaya \\ renymeliana@gmail.com
}

\begin{abstract}
The objectives of this study are: 1. To analyze whether direct compensation and indirect compensation have a significant effect on employee performance at Warung Ayam Goreng Nelongso Klampis, Surabaya. 2. To analyze whether direct compensation and indirect compensation have a significant effect on employee performance through work standard variables as an intervening variable at Warung Ayam Goreng Nelongso Klampis, Surabaya. 3. To analyze whether work standards have a significant effect on employee performance at Warung Ayam Goreng Nelongso Klampis, Surabaya. This research is using quantitative research methods in the form of associative. The population and samples in this study were 32 employees of Warung Ayam Goreng Nelongso Klampis, Surabaya. The sample technique in this study used a sampling census. The analysis technique chosen is The Structural Equation Model (SEM) using Partial Least Square (PLS). The results showed that there was a direct effect between Direct Compensation (X1) on Employee Performance (Y2) but was not significant with a p-value of 0.000 and a $t$ value of 0.261 , there is a direct influence between Direct Compensation (X1) on Employee Performance (Y2) through Work Standards (Y1) but less significant with a p-value of 0.000 and a t value of 0.218 , there is a direct effect between Indirect Compensation (X2) on Employee Performance (Y2) through Work Standards (Y1) has a significant effect with a p-value of 0,000 and a $t$ value of 0.000 , there is a direct influence between Indirect Compensation (X2) on Employee Performance (Y2) which is significantly influential with a p-value of 0,000 and a $t$ value of 0.000 , there is a direct effect between Work Standards (Y1) on Employee Performance (Y2) a significant effect with a p-value of 0,000 and a t value of 0.000 . The results of this study indicate that the variable Indirect Compensation has the strongest influence on Employee Performance compared to other variables.
\end{abstract}

Keywords: Direct Compensation, Indirect Compensation, Work Standards and Employee Performance.

\section{INTRODUCTION}

The existence of business competition that is increasingly competitive today makes every company expect to experience changes that lead to progress and development towards a better one. This competition requires that every company be able to survive and be able to adapt to existing environmental changes. The various strategies developed by companies vary greatly depending on the environment they face. The company must try to improve and develop its company by holding various activities to improve the performance of its employees to achieve company goals, namely to obtain profit (profit oriented). The

The Influence of Direct Compensation and Indirect Compensation through Work Standard Variables as Intervening Variables on Employee Performance at Warung Ayam Goreng Nelongso Klampis, Surabaya

Reny Meliyana Sari, DR. Ir. Rr. Hermien Tridayanti 
strategy carried out by a company requires the support of quality resources, especially human resources. According to Fauziah, Sunuharyo, \& Utami (2016) Management of human resources is science and art that regulates the relationship and role of labor to be effective and efficient in helping to realize the goals of companies, employees, and society. With the existence of good Human Resources, it is expected to be able to demand a company to be better.

Compensation plays an important role in improving employee performance. Someone will work optimally in order to get compensation according to their expectations (Meutia, Sari, \& Tubagus, 2016) Compensation policy in addition to providing compensation to employees for their work is also one of the efforts to retain potential employees. Giving compensation can be done in two kinds of ways, namely by giving direct compensation that can be directly felt by employees and indirect compensation. Direct compensation can be in the form of salaries, wages, incentives and others. Whereas indirect compensation is usually in the form of allowances and several facilities (Zulkarnaen \& Herlina, 2018).

The work standard of a company is a standard set by each company to regulate and provide limits and direction to its employees to carry out all procedures established by a company. Work standards are the basis for the establishment of every company because with the existence of good work standards it will trigger an action or good employee performance. According to Dito (2010) performance or performance is the work that can be achieved by a person or group of people in an organization in accordance with their respective authorities and responsibilities, in order to achieve the objectives of the organization in question legally, not violating the law and in accordance with morals and ethics. Employee performance is a very important thing in the organization's efforts to achieve its goals.

Table 1. Attendance Data for Employees Warung Ayam Goreng Nelongso

\begin{tabular}{llll}
\hline Month & Delay & Work permit & Alfa \\
\hline July & 7 & 9 & 2 \\
\hline August & 16 & 11 & 5 \\
\hline September & 16 & 10 & 6 \\
\hline October & 18 & 5 & 1
\end{tabular}

Source: Processed data from researchers, 2018

The presence of this attendance data shows that there is a lack of timeliness and absenteeism for various reasons carried out by employees at Warung Ayam Goreng Nelongso Klampis, Surabaya. This is possible because the provision of compensation has not been in accordance with the expectations of the employees of the existing payroll. The existence of a payroll system that is less precise and not in accordance with what is expected by employees with the demands of so much work, it will result in a little violation of the rules set by the company.

Warung Ayam Goreng Nelongso Klampis, Surabaya has a strategic location on Jalan Arif Rahman Hakim which includes an area adjacent to several college campuses. In terms of places that are served in this restaurant, it is also interesting, comfortable as a hangout, there is free wifi and according to the needs of consumers now. In terms of the consumer segment, students are a potential segment for culinary or food businesses because most students rarely cook their own food or food, so they must buy their food needs. In the area of business, this also includes a crowded traffic area that is crowded with motorists. This potential should be maintained by paying attention to what consumers want so that consumers get satisfaction and recommend to others. For this reason, an evaluation of what is needed by employees is needed and the effect on improving employee performance through scientific research.

The Influence of Direct Compensation and Indirect Compensation through Work Standard Variables as Intervening Variables on Employee Performance at Warung Ayam Goreng Nelongso Klampis, Surabaya

Reny Meliyana Sari, DR. Ir. Rr. Hermien Tridayanti 
In the business of Warung Ayam Goreng Nelongso Klampis, Surabaya, the availability of such a comfortable place and attractive place decoration, as well as complete physical facilities, cleanliness, neatness, friendly employees and good employee performance are absolutely necessary to support the running of the business. For this reason, research is needed to be able to observe the extent to which employee performance is given to be able to provide satisfaction to consumers.

In terms of fulfilling the good performance of the employees, it is necessary to have an employee performance appraisal process with various supports such as the existence of good compensation for triggering work morale and the existence of good work standards to be able to improve the performance of its employees.

Based on the description of the background above, the researcher is interested in conducting research with the title "The Influence of Direct Compensation and Indirect Compensation through Work Standard Variables as Intervening Variables on Employee Performance at Warung Ayam Goreng Nelongso Klampis, Surabaya".

\section{LITERATURE REVIEW}

\section{Compensation}

According to Larasati (2018) "Compensation is all the rewards received by employees for services delivered by employees to the company". Opinions that are not much different from Alwi (2017) say that compensation is "every form of award given to employees as a reward for the contributions they give to the organization". Compensation is one of the factors either directly or indirectly affecting the high and low performance of employees, therefore compensation should be given to employees need special attention from the management so that employee motivation can be maintained and employee performance is expected to continue to increase (Larasati, 2018). Based on some opinions on the definition of compensation above, it can be concluded that compensation is financial rewards and tangible services and benefits to employees arising from work activities carried out by employees of the company.

There are two types of compensation, namely direct compensation and indirect compensation. Direct Compensation is direct payment in the form of a salary or basic salary overtime and holidays, profit sharing, share distribution and various other bonuses based on employee performance (Mulyadi, 2007). indicators in direct compensation according to Fauziah et al. (2016) are as follows:

1. Salary

Sub indictors of salary include:

a) In accordance with employee expectations

b) In accordance with regulations

c) In accordance with the timeliness of payroll

2. Wages

Sub indicators of wages include:

a) In accordance with the workload carried out

b) In accordance with the provisions that apply every hour

3. Incentives / Bonuses

The bonus sub indicators include:

a) In accordance with applicable regulations

The Influence of Direct Compensation and Indirect Compensation through Work Standard Variables as Intervening Variables on Employee Performance at Warung Ayam Goreng Nelongso Klampis, Surabaya

Reny Meliyana Sari, DR. Ir. Rr. Hermien Tridayanti 
b) In accordance with employee expectations

c) Performed periodically

According to Mulyadi (2007) "Indirect compensation is all payments for employee welfare such as accident insurance, old age insurance, holiday honorarium, sickness benefits". The indicators of indirect compensation according to Fauziah et al. (2016) divided by 3, namely:

1. Allowances that generate income (income).

Sub indicators of benefits include:

a) Holidays Allowance

b) Health insurance

2. Allowance programs that can be viewed as opportunities for employees.

The sub indicators of the benefits program include:

a) Position allowance

b) Holidays

c) Annual leave

d) Sick permission

3. Facilities

The sub indicators of the facility are:

a) Dining facilities

b) Facilities for rest and worship places

c) Parking facilities

\section{Work Standard}

According to Sultan, Saryadi, \& Hidayat (2014) Work Standard is a guideline or reference for carrying out work duties in accordance with the functions and assessment tools of agency / company performance based on technical, administrative and procedural indicators in accordance with work procedures, work procedures, and work systems in the work unit concerned. the clearer the performance standard, the more accurate the level of performance appraisal ". According to Pohan (2010) "Appropriate work standards are guidelines for employees to work effectively and efficiently. Through directed and measurable work standards, it is expected that the company can obtain high-quality work". According to Sultan et al. (2014) standard work indicators include:
a) Technical
b) Administrative
c) Procedure in accordance with work procedures
d) Procedural in accordance with work procedures
e) Work system in the work unit concerned

\section{Performance Employees}

According to Moeheriono (2012) "Definition of performance is a description of the level of achievement of an organization's goals or objectives as a description of the organization's vision, mission and strategic

The Influence of Direct Compensation and Indirect Compensation through Work Standard Variables as Intervening Variables on Employee Performance at Warung Ayam Goreng Nelongso Klampis, Surabaya

\section{Reny Meliyana Sari, DR. Ir. Rr. Hermien Tridayanti}


plan that indicates the level of success and failure in the implementation of activities in accordance with the program and policy set". Performance is the endpoint of certain people, resources, and environment that are collected together with the intention to produce certain things, whether visible products or services that are less visible directly (Fattah, 2017). According to Mangkunegara (2017) employee performance indicators are as follows:

a) Quality of work

b) Honesty of employees

c) Initiative

d) Presence

e) Attitude

f) Cooperation

g) Reliability

h) Knowledge of work

i) Responsible

j) Use of work time

\section{RESEARCH METHODS}

\section{Research Approach}

This study uses an associative quantitative approach. Quantitative approach is a research method that is used to examine a population or a particular sample that aims to test a predetermined hypothesis (Nurcahyani and Adnyani (2016). This study is in the form of associative, namely research that aims to determine the relationship between two or more variables (Nurcahyani \& Adnyani, 2016). The object of this research was conducted by researchers at the Warung Ayam Goreng Nelongso Klampis, Surabaya. The independent variables in this study are direct compensation and indirect compensation, work standards as intervening variables and employee performance as the dependent variable.

\section{Population and Samples}

In this study the population is all 32 employees of Warung Ayam Goreng Nelongso Klampis, Surabaya. In order to get a representative sample of researchers using the census method. This is done because the population is relatively small, so researchers try to take the entire population to be sampled so that the number of samples is 32 samples.

\section{Data Analysis Technique}

The analysis technique chosen to analyze the data and test the hypothesis in this study is The Structural Equation Model (SEM). To answer the hypothesis used Partial Least Square (PLS). According to Ghozali (2014) the calculation is done using a Smart Partial Least Square (PLS) tool, because it is in the form of a multi-lane and the model used is in the form of Reflective.

There are several reasons why in this study PLS data analysis techniques are used, namely:

1. the number of samples used does not have to be large (minimum 30)

2. Not assuming certain distributed data, can be nominal, category, ordinal, interval and ratio.

Ghozali, (2014)The path analysis model of all latent variables in PLS consists of three sets of relationships, including:

1. Inner model that specifies the relationship between latent variables (structural mode)

The Influence of Direct Compensation and Indirect Compensation through Work Standard Variables as Intervening Variables on Employee Performance at Warung Ayam Goreng Nelongso Klampis, Surabaya

Reny Meliyana Sari, DR. Ir. Rr. Hermien Tridayanti 
2. Outer model that specifies the relationship between latent variables with indicators or manifestly variables (measurement mode)

3. Weight relations where assessing cases of latent variables can be estimated. without losing generalization, it can be assumed that the latent variable and the zero means variable variable manifest indicator and unit variance (standardized value) can be removed from the model location parameters (constant parameters).

\section{RESULTS AND DISCUSSION}

Test R Square Adjusted

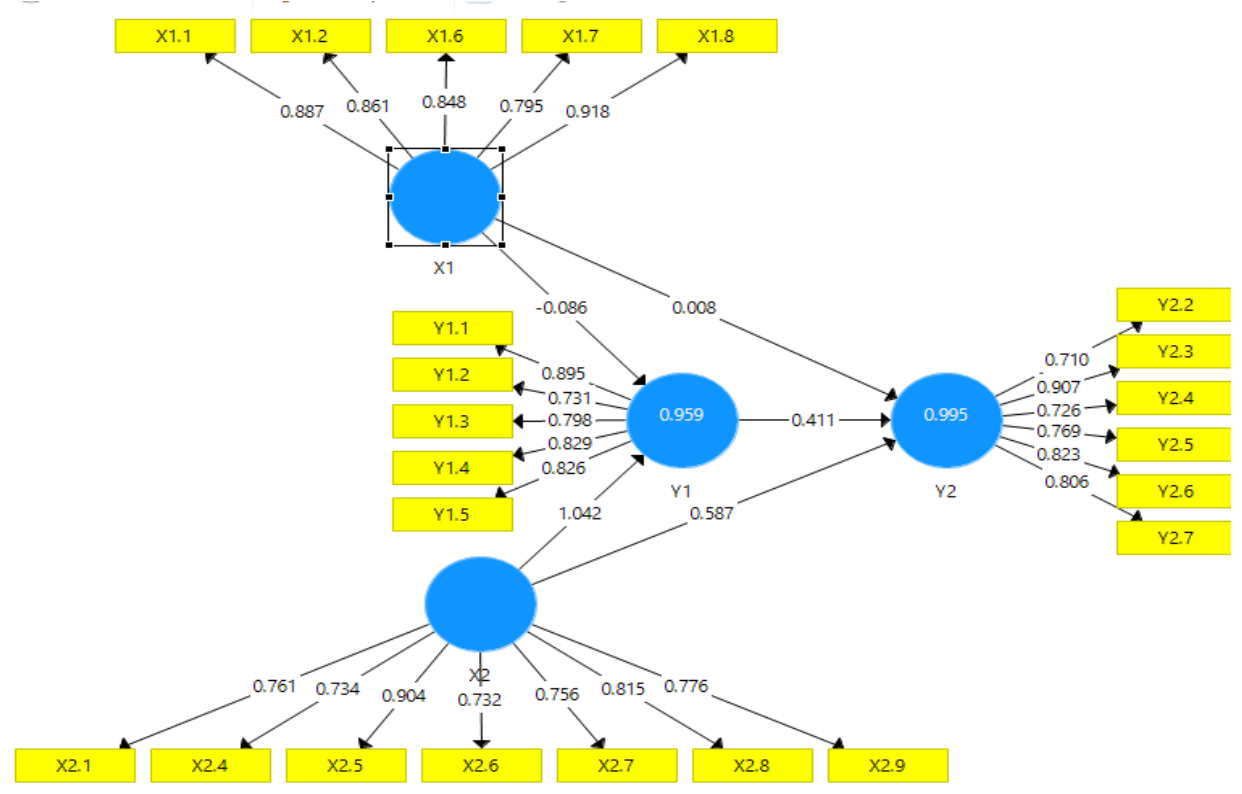

Figure 1. structural model

The results of the Adjusted R Square test show that the Adjusted R Square value for the Working Standard variable (Y1) is obtained at 0.495 for the Employee Performance variable (Y2) obtained at 95.9\% Employee Performance variable (Y1) can be influenced by Direct Compensation (X1), and Indirect Compensation (X2), while Employee Performance (Y2) can be influenced by the variable Direct compensation (X1), Indirect Compensation (X2), and Work Standard (Y1) with a value of $99.5 \%$.

The Influence of Direct Compensation and Indirect Compensation through Work Standard Variables as Intervening Variables on Employee Performance at Warung Ayam Goreng Nelongso Klampis, Surabaya

\section{Reny Meliyana Sari, DR. Ir. Rr. Hermien Tridayanti}


Table 2. Test Hipotesis

\begin{tabular}{|c|c|c|c|c|c|}
\hline & $\begin{array}{l}\text { Original } \\
\text { Sample (O) }\end{array}$ & $\begin{array}{l}\text { Sample } \\
\text { Mean (M) }\end{array}$ & $\begin{array}{l}\text { Standard } \\
\text { Deviation } \\
\text { (STDEV) }\end{array}$ & $\begin{array}{ll}\text { T } & \text { Statistics } \\
\text { (IO/STERRI) }\end{array}$ & P-Value \\
\hline$(\mathbf{X} 1)->(\mathbf{Y} 1)$ & -0.006 & -0.073 & 0.077 & 1.25 & 0.261 \\
\hline$(\mathrm{X} 1)->(\mathrm{Y} 1)->(\mathrm{Y} 2)$ & -0.035 & -0.033 & 0.029 & 1.233 & 0.218 \\
\hline$(\mathrm{X} 2)->(\mathrm{Y} 1)->(\mathrm{Y} 2)$ & 0.428 & 0.423 & 0.053 & 8.132 & 0.000 \\
\hline (X2) -> (Y2) & 0.507 & 0.590 & 0.061 & 9.629 & 0.000 \\
\hline$(\mathbf{Y 1})->(\mathbf{Y} 2)$ & 0.411 & 0.405 & 0.057 & 7.250 & 0.000 \\
\hline
\end{tabular}

\section{Effect of Direct Compensation (X1) on Employee Performance (Y2)}

Based on the results of the analysis using smartPLS, it can be concluded that the Direct Compensation variable has a significant but not significant effect on Employee Performance. This can be seen from the $t$ value of 1.25 . This value is smaller than $t$ table $(1,960)$. Thus, the H1 hypothesis in this study was not accepted. This shows that direct compensation has an effect but is not significant on employee performance in the Warung Ayam Goreng Nelongso Klampis, Surabaya.

This is contrary to the research conducted by Fauziah et al. (2016) which shows that Compensation has a significant effect on employee performance.

\section{Effect of Direct Compensation (X1) through Work Standards (Y1) on Employee Performance (Y2)}

Based on the results of the analysis using smartPLS, it can be concluded that the Direct Compensation variable has a significant but not significant effect on Employee Performance. This can be seen from the $t$ value of 1,233 . This value is smaller than t table $(1,960)$. Thus, the $\mathrm{H} 2$ hypothesis in this study was not accepted. This shows that giving direct compensation through the establishment of work standards has an effect but is not significant on employee performance in the Warung Ayam Goreng Nelongso Klampis, Surabaya.

\section{Effect of Indirect Compensation (X2) through Work Standards (Y1) on Employee Performance (Y2)}

Based on the results of the analysis using smartPLS, it can be concluded that the Indirect Compensation variable has a significant effect on Employee Performance. This can be seen from the t value of 8.132. This value is greater than $t$ table $(1,960)$. Thus, the H3 hypothesis in this study was accepted. This shows that direct indirect compensation through the establishment of work standards has a significant influence on employee performance in the Warung Ayam Goreng Nelongso Klampis, Surabaya.

\section{Effect of Indirect Compensation (X1) on Employee Performance (Y2)}

Based on the results of the analysis using smartPLS, it can be concluded that the indirect compensation variable has a significant effect on employee performance variables. This can be seen from the $t$ value of 9,629 . This value is greater than $t$ table $(1,960)$. Thus, the H4 hypothesis in this study was accepted. This

The Influence of Direct Compensation and Indirect Compensation through Work Standard Variables as Intervening Variables on Employee Performance at Warung Ayam Goreng Nelongso Klampis, Surabaya

Reny Meliyana Sari, DR. Ir. Rr. Hermien Tridayanti 
shows that giving indirect compensation has a significant effect on employee performance in the Warung Ayam Goreng Nelongso Klampis, Surabaya.

This is also supported by research conducted by Zulkarnaen and Herlina (2018). It is known that Direct Compensation has a significant effect on employee performance.

\section{Effect of Work Standards (Y1) on Employee Performance (Y2)}

Based on the results of the analysis using smartPLS, it can be concluded that the work standard variable has a significant influence on employee performance variables. This can be seen from the $t$ value of 7,250 . This value is greater than $t$ table $(1,960)$. Thus, the H5 hypothesis in this study was accepted. This shows that the determination of good work awareness has a significant influence on employee performance in the Warung Ayam Goreng Nelongso Klampis, Surabaya.

This is contrary to the research conducted by Otulia et al. (2017) which shows that work standards do not have a significant effect on employee performance.

\section{CONCLUSIONS AND SUGGESTIONS}

\section{Conclusions}

1. Direct Compensation (X1) has a positive but not significant effect on Employee Performance (Y2) at Warung Ayam Goreng Nelongso Klampis, Surabaya, thus the first hypothesis of the study which reads "Direct Compensation (X1) has a significant effect on Employee Performance (Y2) on Warung Ayam Goreng Nelongso Klampis, Surabaya" is not proven true.

2. Direct Compensation (X1) has a positive but not significant effect on Employee Performance (Y2) through the Working Standard variable (Y1) as an intervening variable at Warung Ayam Goreng Nelongso Klampis, Surabaya, thus the second hypothesis of the study reads "Direct Compensation (X1) has a significant influence on Employee Performance (Y2) through the Work Standard variable (Y1) as an intervening variable at Warung Ayam Goreng Nelongso Klampis, Surabaya "is not proven true.

3. Indirect Compensation (X2) has a significant effect on Employee Performance (Y2) through the Working Standard variable (Y1) at Warung Ayam Goreng Nelongso Klampis, Surabaya, thus the third hypothesis of the study which reads "Indirect Compensation (X2) has a significant effect on Employee performance (Y2) through the Work Standard variable (Y1) as an intervening variable at Warung Ayam Goreng Nelongso Klampis, Surabaya "is proven to be true.

4. Indirect Compensation (X2) has a significant influence on Employee Performance (Y2) at Warung Ayam Goreng Nelongso Klampis, Surabaya, thus the fourth hypothesis of the study which reads "Indirect Compensation (X2) has a significant influence on Employee Performance (Y2) at Warung Ayam Goreng Nelongso Klampis, Surabaya "is proven to be true.

5. Work Standard (X2) has a significant effect on Employee Performance (Y2) at Warung Ayam Goreng Nelongso Klampis, Surabaya, so the fifth hypothesis of the study that reads "Work Standards (X2) has a significant influence on Employee Performance (Y2) at Warung Ayam Goreng Nelongso Klampis, Surabaya."is proven to be true.

The Influence of Direct Compensation and Indirect Compensation through Work Standard Variables as Intervening Variables on Employee Performance at Warung Ayam Goreng Nelongso Klampis, Surabaya

Reny Meliyana Sari, DR. Ir. Rr. Hermien Tridayanti 


\section{Suggestion}

1. In providing Direct Compensation at Warung Ayam Goreng Nelongso Klampis, Surabaya is still considered lacking. There are still many employees who complain and feel unsatisfied with the salary / wages given. Compensation should be expressed in fairness, transparency, compliance with rules and in accordance with the positions of employees by providing good direct compensation that is expected to provide welfare to employees, and make employees improve their performance so that the company's targets are achieved.

2. It is hoped that at Warung Ayam Goreng Nelongso Klampis, Surabaya can apply the Indirect Compensation system properly and appropriately in order to improve its Employee Performance because in the research that occurs the effect of Indirect Compensation has a significant impact on Employee Performance.

3. Establishing Work Standards that are good and more detailed and directed because in this study because Work Standards have the greatest influence on improving Employee Performance.

\section{REFERENCES}

Alwi, M. (2017). Pengaruh Kompensasi, Kompetensi, dan Motivasi terhadap Kinerja Karyawan CV. XYZ. Jurnal Logika, XIX(1), 73-87.

Dito, A. H. (2010). Pengaruh Kompensasi terhadap Kinerja Karyawan PT. Slamet Langgeng Purbalingga dengan Motivasi Kerja sebagai Variabel Intervening.

Fattah, A. H. (2017). Kepuasan Kerja dan Kinerja Pegawai. Yogyakarta: Penerbit Elmatera (Anggota IKAPI).

Fauziah, S., Sunuharyo, B. S., \& Utami, H. N. (2016). Pengaruh Kompensasi Langsung dan Kompensasi Tidak Langsung terhadap Motivasi Kerja Karyawan dan Kinerja Karyawan. Jurnal Administrasi Bisnis (JAB), 37(1), 178-187.

Ghozali, I. (2014). Struktural Equation Modeling Metode Alternatif dengan Partial Least Squares (PLS) dilengkapi Software Smartpls 3.0. Xlstat 2014 dan WarpPLS 4.0. UNDIP.

Larasati, S. (2018). Manajemen Sumber Daya Manusia. Yogyakarta: Grup Penerbit CV Budi Utama (Anggota IKAPI).

Mangkunegara, A. . A. P. (2017). Evaluasi Kinerja SDM. Bandung: Penerbit PT. Refika Aditama (Anggota IKAPI).

Meutia, Sari, I., \& Tubagus, I. (2016). Pengaruh Kompensasi dan Kompetensi dengan Motivasi sebagai Intervening dalam Meningkatkan Kinerja. Jurnal Manajemen, XX(03), 353-369.

Moeheriono. (2012). Perencanaan, Aplikasi dan Pengembangan Indikator Kinerja Utama (IKU) Bisnis dan Publik.

Mulyadi. (2007). Sistem Perencanaan dan Pengendalian Manajemen. Jakarta: Penerbit Salemba Empat.

Nurcahyani, N. M., \& Adnyani, I. G. A. D. (2016). Pengaruh Kompensasi dan Motivasi terhadap Kinerja Karyawan dengan Kepuasan Kerja sebagai Variabel Intervening. E-Jurnal Manajemen Unud, 5(1), $500-532$.

Otulia, P. O., Mbeche, P. I. M., Wainaina, P. G., \& Njihia, J. (2017). Influence of Organisational Resources on Performance of ISO Certified Organisations in Kenya. European Scientific Journal,

The Influence of Direct Compensation and Indirect Compensation through Work Standard Variables as Intervening Variables on Employee Performance at Warung Ayam Goreng Nelongso Klampis, Surabaya

Reny Meliyana Sari, DR. Ir. Rr. Hermien Tridayanti 
13(34), 119-133. https://doi.org/10.19044/esj.2017.v13n34p119

Pohan, A. (2010). Be A Smart Leader. Yogyakarta: Penerbit Pustaka Grhatama (Anggota IKAPI).

Sultan, F., Saryadi, \& Hidayat, W. (2014). Pengaruh Kompensasi, Standar Kerja dan Lingkungan Kerja Terhadap Kinerja Karyawan. Diponogoro Journal of Social and Politic, 1-12.

Zulkarnaen, W., \& Herlina, R. (2018). Pengaruh Kompensasi Langsung dan Kompensasi Tidak Langsung terhadap Kinerja Karyawan Bagian Staff Operasional PT. Pranata Jaya Abadi Banjaran. Jurnal Ilmiah Manajemen Ekonomi Dan Akuntansi, 2(2), 90-114.

The Influence of Direct Compensation and Indirect Compensation through Work Standard Variables as Intervening Variables on Employee Performance at Warung Ayam Goreng Nelongso Klampis, Surabaya

Reny Meliyana Sari, DR. Ir. Rr. Hermien Tridayanti 